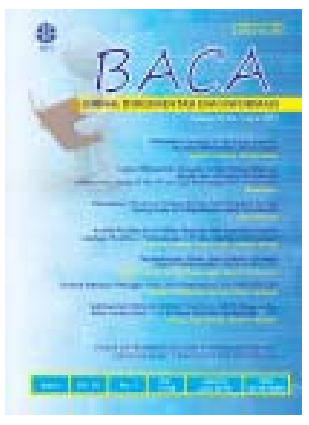

\title{
CITATION ANALYSIS OF COMPUTERS CONTROL SYSTEMS AND INFORMATICS RESEARCHES IN A SINGLE SCIENTIFIC JOURNAL
}

\author{
Engkos Koswara Natakusumah ${ }^{1^{*}}$ \\ ${ }^{1}$ Pusat Penelitian Informatika Lembaga Ilmu Pengetahuan Indonesia \\ *Korespondensi: koswara@informatika.lipi.go.id
}

Diajukan: 15-2-2016; Direview: 5-3-2016; Diterima: 11-3-2016; Direvisi: 2-4-2016

\begin{abstract}
ABSTRAK
Masalah dalam menghasilkan artikel ilmiah yang berkualitas adalah tidak hanya sangat kurangnya sumber literatur baru sebagai referensi, tetapi juga kesulitan dalam menentukan posisi penelitian. Sehingga keberadaannya pada posisi penelitian di dunia ilmiah menjadi tidak jelas. Makalah ini menjelaskan jawaban untuk masalah di atas dengan menggunakan analisis sitiran pada 93 artikel dalam satu jurnal ilmiah. Jurnal yang digunakan untuk penelitian ini adalah Jurnal "Inkom", yang memuat artikel ilmiah tentang informatika, komputer, dan sistem kendali, mulai tahun 2007 sampai 2012 yang dihasilkan oleh Pusat Penelitian Informatika Lembaga Ilmu Pengetahuan Indonesia. Tujuan penelitian ini adalah untuk: (1) mengetahui peringkat pengarang yang terbanyak disitir; (2) mengetahui sarana bibliografi yang terbanyak disitir; (3) mengetahui subyek yang terbanyak disitir. Metode penelitian menggunakan pendekatan kuantitatif melalui analisis bibliometrika untuk mengetahui karakteristik artikel dengan menggunakan analisis sitiran. Hasil dari 667 sitiran artikel menunjukkan bahwa: (1) pengarang yang terbanyak disitir adalah Malvino. Peringkat tiga besar pengarang yang paling banyak di sitir adalah Elan, Murni, dan Rivest; (2) jenis literatur yang terbanyak disitir adalah buku 48,87\%, diikuti oleh sumber literatur yang disitir dari internet sebanyak $18,44 \%$ dan dari jurnal 16,19\%; (3) rata-rata sitiran persatu artikel adalah tujuh; dan (4) subyek yang paling banyak disitir adalah elektronika. Hasil analisis sitiran menunjukkan bahwa ada peningkatan kualitas artikel ilmiah dan kejelasan dalam posisi penelitian ditunjang oleh banyak sumber literatur sesuai yang digunakan untuk referensi pada tahun 2012, ada 197 sitiran dari 17 artikel, sehingga rata-rata sitiran untuk satu artikel adalah 11. Hal ini menunjukkan bahwa ada kenaikan jumlah menggunakan sitiran dibandingkan dengan tahun sebelumnya. Secara umum, cakupan ilmu pengetahuan yang mendominasi sitasi pada Jurnal Inkom adalah subyek elektronika, sensor, dan algoritma. Hasil menunjukkan bahwa ada dominasi sitasi subyek yang berhubungan dengan tahun publikasi: tahun 2007-2009 pada komputer (elektronika), tahun 2011 pada sistem kendali (sensor), dan pada tahun 2012 pada informatika (algoritma).
\end{abstract}

\begin{abstract}
The problems of producing high quality scientific articles are not only using very poor sources of new literature as references, but also difficulties in determining the position of the research. Consequently the existence of research position in the scientific world becomes not clear. This paper explored the answer to those problems statement above using citation analysis method to 93 articles in a scientific journal. The journal used for this research is Journal "Inkom", covering scientific articles of informatics, computer, and control system, from 2007 to 2012, produced by The Research Center for Informatics Indonesian Institute of Sciences. The aims of this research are: (1) to study the most cited authors; (2) to study the most cited bibliographic resources; (3) to study the most cited subjects. In order to achieve those aims, this research uses method of quantitative approach through bibliometrics analysis to study article characteristics using citation analysis. The results from 667 cited articles showed that: (1) the most cited
\end{abstract}


authors is Malvino. Whereas three other most frequent cited authors are Elan, Murni, and Rivest; (2) kind of the most cited literature is book, $48.87 \%$, followed by cited literature from internet $18.44 \%$ and from journals $16,19 \%$; (3) the average of cited literature perarticle is 7; and (4) the most cited subjects is electronics. The results of citation analysis showed that there are increasing quality of scientific articles with clear research position, supported by appropriate literature sources. In 2012 there are 197 citations from 17 articles, the average of citation for one article is 11 , this means that there are increasing numbers of using the citation compared to the year before. In general, the science coverage dominating citations in Journal "Inkom" are the subjects of electronics, sensors and algorithms. The result showed that there are dominating subjects citations related to the year of publications: 2007-2009 in computers (electronics), 2011 in control systems (sensors), and 2012 in informatics (algorithms).

Keywords: Bibliometrics analysis; Citation analysis; Scientific journal

\section{INTRODUCTION}

Citation analysis is a branch of information science in which the way articles in a scholarly field are accessed and reference is studied. It was developed to identify core articles, authors, or journals in a field (Meho, 2007). It reveals the relationships between works that are represented by references (Garfield, 2004), and thus can guide collection development in academic libraries (Johnson, 2000). Citation analysis is defined as that subfield of informetrics where patterns and frequencies of citations, given as well as received are analyzed. Such an analysis is performed on the level of authors, journals, scientific disciplines and any other useful unit or level. Citation analysis further studies relations between cited and citing units (documents, authors, countries etc.). From an application point of view citation analysis may be considered as a collaborative peer effort to analyze and promote the quality of scholarly publication and research (Rousseau, 2008).

One activity of a research institution is to carry out research appropriate to subject area. The research can be done by a single or a group of researcher(s), depends on research coverage and topic. In general, most of research topic in engineering science is carried out by a group, whereas in social science is done by single researcher (Natakusumah, 2014). Purpose of research is to produce a new finding that can increase quality and productivity of the output. That is why, in making a research planning we need support of many appropriate literature from primary and secondary sources. The most appropriate literature source for scientific research is new scientific journals. Those journals are used for references to know the state of the art of the research, if it is a new research, previously developed research or selected and combined several research methods to be one appropriate method. So that the research position can be measured and given a new contribution to development of science. A scientific article must have source of literature as a cited document and also supporting written, analysis, development of new theory or method. Sources of cited document are put in a list of references at the end of article with a certain format. This is a kind of code of ethic in a research, where a new scientific article is accumulated previous scientific articles. Citation of an article is a common use to write a scientific article. This citation is also used as a scientific proof to decrease a research subjectivity, so that the objectivity is increasing and also improving quality of scientific article.

Whenever making report something that have read, have an ethical and a practical responsibility to cite where read it. Ethically, need to give credit to other authors for their words and ideas. Practically, citations identify sources to the interested reader. Citing sources is essential in research papers, 
which rely heavily on empirical evidence. When citing references, use the conventions of the discipline, so that key information appears in a consistent way that everyone can understand. There are two parts to completing the citation of a source. The first, it must cite the source in the text of the paper, and the second, it must list all sources, in a standardized format, on the References page.

Scientific publication is an important activity for a scientific research in every country, especially in a developing country (Jacobs, 2001), that is why, it needs a study of publication through bibliography of the paper. Bibliography analysis is carried out by every one dealing with information world. Information has developed very fast and scatteredly, it needs identifying and knowing the development in society. According to Glanzel (2003), the term of bibliometrics was firstly used by Pritchard (1969) in his article "Statistical Bibliography or bibliometrics" published in the "Journal of Documentation". Biblio means book and Metric means a scale or measure. Bibliometrics means application of statistical studies in library and information science. Pritchard (1969) explained that bibliometrics is defined as "the application of mathematics and statistical methods to books and other media of communication". This statement is parallel announced by Reitz (2004), bibliometrics is a term used in mathematical and statistical methods to learn and identify of using library sources and services or to analyze development of special literature, especially for author, publication and the user. Bibliometrics is an output indicator for a researcher capability in a certain subject. Von Ungern-Sternberg (1995) explained bibliometrics method give possibility to draw a content, structure and development of the research. Davis and Wilson (2011) said that bibliometrics indicator is used broadly to mark research activity in a context of research policy.

In General, the purpose of bibliometrics is to explain written communication process, calculation descriptive and analysis of facet communication. Bibliometrics is divided into two group (SulistyoBasuki, 2002), those are: (1) publication distribution, this group is quantitative analysis to literature, started by basic law of bibliometrics: (a) Lotka's Law calculates productivity distribution of scientific researchers; (b) Bradford's Law of Scatter describes how the literature of a subject area is distributed in its journals and forms the basis for calculating how many journals contain a certain percentage of published articles; (c) Zipf's Law describes the frequency of the appearance of certain words or more specifically suggests that people are more likely to select and use familiar rather than unfamiliar words; and (2) citation analysis started by Garfield. Citation is a reference to a published or unpublished source. More precisely, a citation is an abbreviated alphanumeric expression embedded in the body of an intellectual work that denotes an entry in the bibliographic references section of the work for the purpose of acknowledging the relevance of the works of others to the topic of discussion at the spot where the citation appears. Generally the combination of both the in-body citation and the bibliographic entry constitutes what is commonly thought of as a citation. A prime purpose of a citation is intellectual honesty to attribute prior or unoriginal work and ideas to the correct sources and to allow the reader to determine independently whether the referenced material supports the author's argument in the claimed way.

Citations are measured to find the different use patterns like author, chronology, geography, subject, forms etc in library and information science. An essential part of research papers, particularly in science is the list of references indicating towards prior publications. Ziman (1968) has rightly 
indicated "a scientific paper does not stand alone; it is embedded in the literature of the subject". Similarly Narin (1976) defines "A reference is the acknowledgment that one document gives to another; a citation is the acknowledgment that one document receives from another”. Malin (1968) says "A citation implies a relationship between a part or the whole of the cited document and a part or the whole of the citing document.” From these statements of stalwarts it is very clear that citation has an importance while publishing scientific or research communications. It is a must to cite the author from which data is used. Research activity is built on citing papers and using previous knowledge. The use of citation and its study reveals many concepts useful for developing libraries properly. Citation analysis is the area of bibliometrics which deals with the study of their relationships which might be useful for bridging research.

One of the information study dealing with a list of literature is citation analysis. Citation analysis method is one of a bibliometrics technique in library and information science areas, studies relation between citation and cited documents. According to Diodato (1994) citation analysis is a study in the area of bibliometrics that study of citation from a document. Garfield (1983) defined citation analysis as "the examination of the frequency, patterns, and graphs of citations in articles and books". Content analysis uses citations in scholarly works to establish links to other works or other researchers. Citation analysis is one of the most widely used methods of bibliometrics. Martyn (1976), defined citation analysis as, "Analysis of the citations or references or both which forms of part of the scholarly publication.” According to Baughman (1974), “Citation study is a systematic inquiry into the structural properties of the literature of the subject" he explains that the structure of literature is of a good quality.

In 2009, Herther studied the research evaluation and citation analysis. Her findings showed that as more sources for citation information have become available and many scholarly databases today offering cited reference data, there is a need to identify access and manage these resources. Information professionals need to become more proactive in their strategies to support these applications and users. Garfield studied citation indexes for retrieval and research evaluation in 2004. The purpose of his study was to develop, using objective criteria, a statistical procedure to evaluate the importance of scientific journal articles. In 1998, Sylvia studied citation analysis as an unobtrusive method for journal collection evaluation, using psychology student research bibliographies. She found that the most cost effective and the most used materials were usually held by the library.

According to Garfield (1983) an author cited other author because of several reasons: giving salute to author or paper in his subject, identification of methodology or theory, giving back ground reading to those who want to know further topic that already written, correction paper, giving criticisms to the paper previously published, strengthen claim to a finding and as a reference to other writers that want to learn in depth of cited paper. Garfield said that in using citation analysis, there are problems to be counted; author paper to be focused; type of document source, such as article, paper, book, thesis and dissertation; and multi discipline subjects have difficulties in subject analysis. The frequent object study in citation analysis is a list of bibliography or a list of literature, mentioned at the end of the paper in a journal. Aspects study in citation analysis are: (1) citation form covers a number of citation, a number of auto citation or author cited his own article; (2) literature characteristic, dealing 
with cited article by author in a journal/proceeding/book, covers types, year of publication, language of cited literature; and (3) author opal consists of a number of author, the most cited author, single or many authors.

Citation analysis in bibliometrics study has a way to determine several policy. Bibliometrics study uses many citation analysis as a way to determine policy (Hartinah, 2002), such as: (1) evaluation of research program; (2) determination of science; (3) visualization of discipline science; (4) indicator of science and technology; (5) impact factor of journal; (6) quality of journal; and (7) development of journal collection, etc. So that, citation analysis is used for policy. Citation analysis is useful for analysis every science subject to evaluate book, journal or author that is most cited by other author or journal. In conclusion, citation analysis is a part of bibliometrics study and cited document in a scientific paper. Aspect to be studied in citation analysis depends on the need of researcher or author.

A researcher must know the criteria of cited document in a reference. A document is cited by an author or a researcher, if cited documents are relevant to the activities then used as a reference for scientific paper. Not all related documents can be cited, only the appropriate document to the research topic can be selected. Usability of document for researcher not only dealing with a relevance topic but also with the new, good quality and credible document. Document with high usability will be marked by researcher and determined whether the document is used for citation or not. A researcher must know criteria in document citation that can be used as a citation, the document must be relevant to write activity of the scientific paper. The criteria is not only inside document, outside document factor and new document are also important parts of research of cited document.

The questions appear, are there possibilities of certain scientific articles use the same literature sources for citation? This can be seen in using a standard journal, author and the late source of literature. To know the type and source of literature needed by researcher, we can can do a certain analysis. One of the analysis to know the need of researcher is using citation analysis to every articles of research product that is used as material for citations or a list of references. That is why, it is important to carry out research on bibliometrics using citation analysis to a scientific journal. This research uses Journal "Inkom” as a source of data to be analyzed. This is a scientific journal, published twice a year, consisting of scientific articles in the subjects field of informatics, computers and control systems. The result of this research will give input to the Research Center for Informatics, to understand the characteristics of scientific articles in the journal.

Based on the background of research explained above, then research problems appear, how is the form of citation, literature characteristics and the opal of author in a source of cited literature published in the journal. Some research questions appeared are: (1) who is the most frequently cited author in the journal?; (2) what kind of literature sources frequently cited?; (3) what is the average of cited document for every article?; and (4) what kind of subject frequently cited?

Frame of thought in this research becomes a guidance in doing a research. Articles from Journal "Inkom” period 2007 until 2012 become a material for citation analysis. Aim of this research is to answer the research questions above, those are: (1) to study rank of authors that are mostly cited in the journal; (2) to study what kind of bibliography data frequently cited; (3) to study the average of cited document per article; and (4) to study the most frequently cited subject. 
Output of this research is useful for: (1) researcher, doing analysis to reference data, can measure the impact of a journal/book/proceeding, author, publication and publisher. More frequent cited literature, then more impact to the development of science and technology. Analysis cited data help researcher understand coverage and kind of titles had been researched, this makes easy to select a new title to be researched; (2) research Center for Informatics, output of the research can be used for development and evaluation of library collection, to have the collection appropriated to the need of researchers; and (3) library and information sciences, this research output can be used as reference or added literature in bibliometrics subject, especially in citation analysis.

\section{METHODS}

Citation in research works is used to establish links to other works. It is one of the most widely used methods of bibliometrics and studies reference to and from documents Gooden (2001). The benefit of bibliometrics and citation analysis is expressed by Van Raan (2003), which is reinforced by the studies (Aksnes, 2006) that have used this method of research inquiry to evaluate a library collection. Citation analysis reveals interesting information about knowledge producers in terms of their information seeking behavior and usage of various information sources. It can highlight the familiarity, awareness and usage of knowledge producers regarding the online and print information sources. Citation analysis examines the frequency, patterns and graphs of citations in articles and books (Garfield, 1983). Method of citation analysis is one of bibliometrics technique in library and information science, study relations between cited document and citation document. This research is carried out by using quantitative method in bibliometrics analysis to measure the characteristics of articles using citation analysis. Research instrument used to get data for this research is secondary data with documented method. Secondary data covers literature that give information about primary literature including in secondary data such as bibliography, index journal, abstract journal, catalog. Secondary data used are a list of literature or bibliographies from articles available in the journal "Inkom” from 2007 up to 2012.

Data gathering in this research is citation analysis method. Citation data used are available in a list of literature in every article in the journal, then tabulated to make easy to be analyzed and discussed. Data collections have several steps, those are: (1) looking for data from the journal in the Library of the Research Center for Informatics; (2) selecting accessory of bibliographic data in every article; (3) recording citation data which consists of author, title of article, volume, year of publication, place of publication, publisher, type of literature, language of literature and name of the journal; and (4) inputting the data to the computer to make the working process easy.

Collected data is processed, and put in a Table form so that easy to be read and interpreted. Data interpretation is conducted to look for a broad meaning and the implication of the data presented. The steps of analysis and data presentation are carried out as follows: (1) author rank to analyze author that frequently cited, input author name to the computer, give rank to the output and put the data into the table, then do data interpretation to the output; (2) literature rank to determine what kind of literature frequently cited, input data to the computer, sort from frequently cited article, then make interpretation to process data; (3) subject rank the most frequent research to determine subject rank, input data to computer, sorting from the most frequent research, then do interpretation to the process 
data; (4) calculate the average of a number of citation in every article in the journal.

\section{RESULT AND DISCUSSION}

Citations from the references in each articles are extracted for content analysis. They are analyzed from journals, books, conference papers, internet, data sheets, technical reports, standards, research reports patent, yearly reports, thesis, and dissertations. The Journal "Inkom" had extracted all the details such as population of the journals, numbers of citations, the most cited authors, type of cited literature, and rank of cited literature.

\subsection{Population of Journal "Inkom"}

Populations of this research are all numbers of journal "Inkom” published from 2007 up to 2012. Samples of this research are all articles that appear in a population. The population can be seen in Table 1.

Table 1. Population of journal "Inkom”

\begin{tabular}{|c|c|c|c|c|c|c|c|}
\hline No. Journal & $\mathbf{2 0 0 7}$ & $\mathbf{2 0 0 8}$ & $\mathbf{2 0 0 9}$ & $\mathbf{2 0 1 0}$ & $\mathbf{2 0 1 1}$ & $\mathbf{2 0 1 2}$ & Total \\
\hline 1 & 8 & 8 & - & 7 & 7 & 10 & 40 \\
2 & 8 & 9 & $13^{*}$ & 6 & 10 & 7 & 53 \\
\hline Total & $\mathbf{1 6}$ & $\mathbf{1 7}$ & $\mathbf{1 3}$ & $\mathbf{1 3}$ & $\mathbf{1 7}$ & $\mathbf{1 7}$ & $\mathbf{9 3}$ \\
\hline
\end{tabular}

Table 1 shows the number of analyzed 93 article samples, 16 articles from 2007, 17 articles from 2008, 13 articles from 2009, 13 articles from 2010, 17 articles from 2011 and 17 articles from 2012. Those data show that the number of articles in every year changes, consequently, the number of article published in every volume is not consistent. In a journal publication, consistency of the number of articles published shows a good journal management. Inconsistent articles published frequently happen in every new journal publication with bad management, journal is not recognized by researcher, the number of article published is always with different numbers, depending on the articles submitted. If the articles calling is extremely minimum then it will be difficult for the editor to do a good selection with maximum quality of articles. This minimum article can decrease the quality of article published. This inconsistent publication showed in the year 2009. In 2009 it was supposed to be published in two volumes, but because of lack of articles then the two volumes were incorporated in to one volume in one publication.

\subsection{Citation of the Journal}

Citations play an important role in research. They added that scientific paper or scientific research does not go alone, but embedded in the subject of literature, as a reference (citation) which is acknowledgment for the use of information by the another author who cites in his writing. The relation of cited and citing document states "a citation implies relationship between a part or the whole of the cited document and a part or the whole of the citing document." Citation analysis 
is the area dealing with the bibliometrics and with the study of relationship of cited and citing document and such studies are essential to track the scholarly development in any subject field. Nicholas (1978) in his article "Literature and Bibliometrics" explained the importance of citation analysis and its applications in library and information science. He pointed out that information scientists and librarians use citation analysis to quantitatively assess the core journal titles and watershed publications in particular disciplines; interrelationships between authors from different institutions and schools; and related data about the academia. Some more pragmatic applications of this information includes the planning of retrospective bibliographies, finding the age of material used in a discipline, and comparison between the use of recent publications versus older ones, comparing the coverage of secondary services which can help publishers gauge their achievements and competition, and can aid librarians in evaluating "the effectiveness of their stock". There are also some limitations to the value of citation data. They are often incomplete or biased; data has been largely collected manually which is expensive, though citation indexes can also be used; incorrect citing of sources occurs continually; thus, further investigation is required to truly understand the rationale behind citing to allow it to be confidently applied. Thus it is revealed that bibliometrics method is very useful to analyze the impact of literature in any subject areas and in library and information science, it is useful to decide the policies for different activities like acquisition, organization, stacking, introduction of new service, ranking of periodicals, half life of literature in any subject discipline formatting and collection development policies and related policies.

Journal “Inkom” published by the Research Center for Informatics in Bandung from 2007 until 2012 have 93 scientific articles. Citation from the journal can be seen in Table 2.

Table 2. Citation from Journal “Inkom” 2007-2012

\begin{tabular}{|c|c|c|c|c|c|c|c|}
\hline No. Journal & $\mathbf{2 0 0 7}$ & $\mathbf{2 0 0 8}$ & $\mathbf{2 0 0 9}$ & $\mathbf{2 0 1 0}$ & $\mathbf{2 0 1 1}$ & $\mathbf{2 0 1 2}$ & Total \\
\hline 1 & 58 & 50 & - & 51 & 42 & 71 & 272 \\
2 & 47 & 44 & $72 *$ & 43 & 63 & 126 & 395 \\
\hline Total & $\mathbf{1 0 5}$ & $\mathbf{9 4}$ & $\mathbf{7 2}$ & $\mathbf{9 4}$ & $\mathbf{1 2 9}$ & $\mathbf{1 9 7}$ & $\mathbf{6 6 7}$ \\
\hline \multicolumn{7}{|c}{ (* Number 1 dan 2 incorporated in one publication) }
\end{tabular}

Table 2 shows a number of 667 citations from 93 articles, the average citation per article is 7 citations in each article. Up to know, the number of citation in an article daoes not have a clear regulation, especially related to border of maximum and minimum citations used in one scientific article. But enough numbers of appropriate and relevant literature have a good support to the research and written scientific article, more cited literatures in a scientific paper has indicated many literature used as references. Many references used in new scientific journals show that the research has a good quality and up to date. Many primary article or cited paper show that author uses intensive information, so that his article has a good quality. The number of cited literatures depend on the author's need to support his scientific articles.

Smith (1981) said that there are several possibilities why a scientific paper only cited minimum literature: (1) it is difficult to have literature appropriate to the research topic, do not know the tool to search source of reference information; (2)the research topic is quite new so that there 
are not many appropriate literature or publications available; (3) the authors feel safe with enough numbers of reference literature to support the research and his written article; (4) the authors do not know the availability of needed literature; (5) the authors do not understand language used in the literature searched; (6) the authors do not understand how to cite documents; (7) the authors are lack of information to access and get appropriate literature.

According to Liu (1993), the number and type of cited literatures by researcher depend highly on the library collection in the institution where the researcher works. For special research, it depends very much on special collection available in the library, price of special collection which is relatively expensive. But for general collection in public domain, it can now be accessed through internet facility to get an appropriate literature.

\subsection{More Frequently Cited Authors}

When one author cites another author, a relationship is established. Citation analysis uses citations in scholarly works to establish links. Many different links can be ascertained, such as links between authors, scholarly works, journals, fields, or even countries. Citations both from and to a certain document may be studied. One very common use of citation analysis is to determine the impact of a single author on a given field by counting the number of times the author has been cited by others. The most cited author can be seen from citation used in every scientific articles in the journal. From 667 documents, the most cited author is shown in Table 3.

Table 3. More Frequently Cited Authors

\begin{tabular}{|l|c|c|c|c|c|c|c|}
\hline Author & $\mathbf{2 0 0 7}$ & $\mathbf{2 0 0 8}$ & $\mathbf{2 0 0 9}$ & $\mathbf{2 0 1 0}$ & $\mathbf{2 0 1 1}$ & $\mathbf{2 0 1 2}$ & Total \\
\hline Wasito, S. & 2 & 1 & - & - & - & - & 3 \\
Malvino, A. P. & 3 & 2 & 2 & - & - & - & 7 \\
Djaelani, E. & - & 2 & 3 & - & - & - & 5 \\
Sustika, R & - & - & - & 3 & - & - & 3 \\
Tan P. & - & 1 & - & 1 & - & 1 & 3 \\
Kusumoputro B. & - & - & - & - & 3 & - & 3 \\
Setiawan W. & - & - & - & - & 3 & - & 3 \\
Murni A. & - & - & - & - & 5 & - & 5 \\
Rivest R. & - & - & - & - & - & 4 & 4 \\
Chan H. & - & - & - & - & - & 3 & 3 \\
\hline Total & $\mathbf{5}$ & $\mathbf{6}$ & $\mathbf{5}$ & $\mathbf{4}$ & $\mathbf{1 1}$ & $\mathbf{8}$ & $\mathbf{3 9}$ \\
\hline
\end{tabular}

Table 3 above shows that there are three top ranks of cited author, the first rank is Malvino, A.P., 7 times cited by other authors, the second is Djaelani E., 5 times cited, the third is Chan H., 4 times cited by other authors. The rest authors: 2 and 1 times cited by other authors do not appear in the Table 3. Malvino, A.P. is the most frequently cited; 3 times in 2007,2 times in 2008:, 2 times in 2009. The source of literature is the books with the subject of electronics. This shows that book dominates to be a literature source frequently used in 2007 until 2009, especially for the subject of 
computers. The second author rank is Elan Djaelani, cited 5 times, 2 times in 2008, 3 times in 2009 with the subject of electronics. Those facts show that there are dominant cited electronics document in the journal. The third author rank is Munir A., cited 5 times with subject of sensor in the year 2011. Sensor is a part of control systems. The fourth author rank is Rivest, cited 4 times in the year 2012 with subject on algorithm. Algorithm is part of informatics, this is a relatively new subject, dominating to new references. In general, the science area dominating citations in journal "Inkom" are electronics, sensor, and algorithm. The result shows that there are dominating subject citation related to the year of publications: in 2007-2009 on computers, in 2011 on control systems and in 2012 on informatics.

\subsection{Sources of Cited Literatures}

Citation analysis is one kind of library evaluation used to help collection management. This analysis technique gives a deep meaning to appear new power and research about backdate literature or collection. Citation analysis study is supported by fast development of scientific journal growth and push information specialist to develop citation analysis method to study a journal. Bibliometrics studies record information, especially information in graphic form, so the object studies are journal, proceeding, book, internet, theses, dissertation, data sheet, technical report, yearly report, research report, Indonesia Nasional Standard (SNI) and patent. Cited literature for every sources of citation can be seen at Table 4 .

Table 4. Sources of Cited Literatures

\begin{tabular}{|l|c|c|c|c|c|c|c|c|}
\hline Sources of Citation & $\begin{array}{c}\text { Volume } \\
\text { Journal }\end{array}$ & $\mathbf{2 0 0 7}$ & $\mathbf{2 0 0 8}$ & $\mathbf{2 0 0 9}$ & $\mathbf{2 0 1 0}$ & $\mathbf{2 0 1 1}$ & $\mathbf{2 0 1 2}$ & Total \\
\hline Journals & 1 & 3 & 3 & 28 & 1 & 1 & 8 & 44 \\
Proceedings & 1 & 2 & 1 & 8 & 4 & 7 & 9 & 31 \\
Books & 1 & 34 & 26 & 28 & 19 & 24 & 39 & 170 \\
Internet & 1 & 17 & 13 & 6 & 24 & 5 & 9 & 74 \\
Thesis & 1 & 1 & 1 & 1 & 3 & 5 & 5 & 16 \\
Data sheet2 & 1 & 1 & 2 & - & - & - & - & 3 \\
Technical reports & 1 & - & 3 & - & - & - & - & 3 \\
Yearly report & 1 & - & 1 & - & - & - & - & 1 \\
Research report & 1 & - & - & 1 & - & - & - & 1 \\
SNI & 1 & - & - & - & - & - & 1 & 1 \\
\hline Journals & 2 & - & 3 & - & 3 & 9 & 49 & 64 \\
Proceedings & 2 & - & 2 & - & 2 & 6 & 33 & 43 \\
Books & 2 & 34 & 34 & - & 17 & 32 & 3 & 155 \\
Internet & 2 & 8 & 5 & - & 20 & 13 & 3 & 49 \\
Thesis & 2 & 1 & - & - & - & - & - & 1 \\
Dissertation (PhD) & 2 & - & - & - & 1 & 1 & - & 2 \\
Data sheets & 2 & 3 & - & - & - & - & - & 3 \\
\hline
\end{tabular}


Citation Analysis of Computers Control Systems ... | Engkos Koswara N.

\begin{tabular}{|l|c|c|c|c|c|c|c|c|}
\hline $\begin{array}{l}\text { Technical reports } \\
\text { Patent }\end{array}$ & 2 & 1 & - & - & - & 1 & 2 & 4 \\
\hline & 2 & - & - & - & - & 1 & - & 1 \\
\hline
\end{tabular}

Table 4 shows citation data from various literature sources in Journal "Inkom”, volume 1 and 2. There are 105 citations in 2007, 94 citations in 2008, 72 citations in 2009, 94 citations in 2010, 105 citations in 2011, 197 citations in 2012. In volume 2, 2012 shows that journals are the most utilized citation in the journal: 49, followed by books 39, proceedings 33, Internet 3 , and technical report 2. This finding citation journals are still in line with the finding of Olatokun and Makinde (2009), analyzed dissertations submitted to the Department of Animal Science, University of Ibadan, Nigeria during the period of 2000-2007. Their findings show that journals are the most utilized reference materials in the dissertations. This citation journal shows that knowledge of researcher to use citations increases significantly, and also shows that research quality is also increasing. Table 4 has difficulties to show the citation literature rank. It needs to be changed to be Table 5 which is arranged based on cited literature rank, also can see literature rank, type of literature, number of citation and percentage of citation.

Table 5. Rank of Cited Literatures

\begin{tabular}{|c|c|c|c|}
\hline Rank of Order & Sources of Citation & Number of Citations & Percentage \\
\hline 1 & Books & 326 & 48,87 \\
\hline 2 & Internet & 123 & 18,44 \\
\hline 3 & Journals & 108 & 16,19 \\
\hline 4 & Proceedings & 74 & 11,09 \\
\hline 5 & Thesis & 17 & 2,55 \\
\hline 6 & Technical report s & 7 & 1,05 \\
\hline 7 & Data sheets & 6 & 0,90 \\
\hline 8 & Dissertation of $\mathrm{PhD}$ & 2 & 0,31 \\
\hline 9 & Technical report & 1 & 0,15 \\
\hline 10 & Research report & 1 & 0,15 \\
\hline 11 & Patent & 1 & 0,15 \\
\hline \multirow[t]{2}{*}{12} & “Standar Nasional Indonesia” & 1 & 0,15 \\
\hline & Total & 667 & 100 \\
\hline
\end{tabular}

Table 5 shows rank of cited literatures of 12 sources of citation, those are citations of books $48,87 \%$, followed by Internet $18,44 \%$, journals $16.19 \%$, proceedings $11,09 \%$, thesis (S2) $2,55 \%$, and technical report $1,05 \%$. The rest types of documents are cited less than $1 \%$, covering data sheet $0,90 \%$, dissertation (S3) $0,31 \%$, yearly report $0,15 \%$, research report $0,15 \%$, patent 
$0,15 \%$ and standard $0,15 \%$. In other words, books are the primary sources of information in the research studies of computers and control systems. This finding is similar to the finding of Nikko and Adetoro (2007) who discovered that this category of authors cited more books to the tune of $53.3 \%$.

Variety of using literature types of articles in the journal is extremely good, showing that researchers are capable of utilizing various literature available based on research need. Book is a literature that gives the most contribution to writing article in the journal, it is 325 book citation, the second rank comes from sources of internet with 123 internet citations, the third rank comes from journal with108 journal citations. As we know that journal consists of new information about scientific articles produced by researchers. But why is journal in the third rank not in the first one instead? One of the reasons is that many researchers have difficulties in getting scientific journals because the price is so expensive and many local libraries are short of journal collections, compared to the book which is always available in the local library. Internet is 24 hours available to support literature and easy to use,thus it is very useful for researcher to have relevant references. In conclusion, book dominates as a source of literature in writing article for journal "Inkom", compared to other sources of literature. Book is easier to get than the other sources because most of books are available in the library near campus and in book stores. Internet in the second rank used as source of information after book collection. This shows that internet has information on source of information required by researcher for supporting research activity.

Based on data analysis above, internet is so useful in the information era that it is used as citation in the second rank after book. This situation is caused by several problems of using internet, either from internal and external factors. Problem of internal factor comes from the researcher himself, such as: (1) researcher has limited knowledge to access new appropriate scientific journal in the internet; (2) researcher needs proper time to access the internet; and (3) internet does not become priority. Problems of external factor are: (1) the number of internet facility is limited; (2) internet access quality is poor, especially internet bandwidth capacity is relatively small and has difficulty in downloading a literature file; (3) some information available in the internet are not relevant for scientific literature. Scientific journal, which is in the third rank, is supposed to be in the first rank for scientific literature citation, the problem is that it is relatively expensive to get printed scientific journals and not many libraries provide them in their collections. Availability of online scientific journal databases is still limited and relatively expensive to be accessed.

\section{CONCLUSION}

Citation analysis of single scientific journal is useful in determining information sources which are vital for researcher studies in a given subject area on computers, control systems, and informatics. They may also help the Research Center Library in their budget planning to judiciously use their budgets and funds to make far reaching decisions on library material collection. The research was carried out to 93 articles in the Journal "Inkom” published in the year 2007 up to 2012 with 667 citations. The result of citation analysis shows that there are four authors rank dominating the citations 
namely Malvino, Elan, Murni and Rivest. Malvino is an author that is mostly cited from 2007 until 2009, followed by Elan from 2008 up to 2009, Murni in 2011 and Rivest in 2012. The most articles cited from Malvino and Elan are in the subject of electronics, Murni in sensors and Rivest in algorithm. This shows that subjects of electronics and sensors are the most dominant in the journal related to area of computers and control systems. Whereas algorithm is part of informatics area, the most new citation in 2012. This proves that informatics is relatively new subject compared to computers and control systems. The authors rank are in the subjects of computers, control system and informatics respectively. The science area dominating citations in journal "Inkom” are electronics, sensors, and algorithms. The result shows that there are dominating subject citations related to the year of publications: in 2007-2009 on computers (electronics), in 2011 on control systems (sensors) and in 2012 on informatics (algorithms). The most type of cited literature is book, 48,87\%, followed by source of literature from internet, $18,44 \%$, then journal $16,19 \%$. Book has dominated to be the reference in written article in journal, compared to other literature. Book is easier to get in local library near campus and book store nearby. Source of literature from internet is the second source used by researchers, showing that internet has huge collection that some of them appropriate to the research literature. The average of articles cited in 2007 until 2012 are 7 citation per article. 2012 has dominated citation with 197 citations from 17 articles, the average is 11 citation per article. The result of analysis shows that researcher knowledge to use citation increases significantly, there is also shown the increasing research quality.

\section{REFERENCES}

Aksnes, D.W. 2006. Citation Rates and Perceptions of Scientific Contribution. Journal of the American Society for Information Science and Technology, 57(2), p.169-185.

Bhughman, J C. 1974. A Structural Analysis of the Literature of Sociology. Library Quarterly, Vol. 44 (Oct), p. 293-308.

Davis, M., Wilson, Concepcion S. 2001. Elite Researchers in Ophthalmology: Aspects of Publishing Strategies, Collaboration and Multidisciplinary. Scientometrics, 52 (3), p.395-410.

Diodato, V. 1994. Dictionary of Bibliometrics. New York: The Haworth Press, Inc.

Garfield, E. 1983. Citation Indexing - Its Theory and Application in Science, Technology and Humanities. Philadelphia: ISI Press.

Garfield, E. 2004. Citation Analysis as A Method of Historical Research Into Science. (http:// www.garfield.library.upenn.edu/ci/chapter7.pdf, accessed April 5, 2016, hour 12.46).

Glanzel, W. 2003. Bibliometrics as a Research Field: A Course on Theory and Application of Bibliometrics indicator.

Gooden, A.M. 2001. Citation Analysis of Chemistry. Doctoral Dissertations: An Ohio State University Sase Study.

Hartinah, Sri. 2002. Analisis sitiran. Dalam Makalah Kursus Bibliometrika.Pusat Studi Jepang

Herther, Nancy K. 2009. Research Evaluation and Citation Analysis: Key Issues and Implications. The Electronic Library, 27(3), 361-375.

Jacobs, Daisy. 2001. A Bibliometrics Study of the Publication Patterns of Scientists in South Africa 19921996. In The 8th International Conference on Scientometrics and Informetrics Proceedings ISSI- 2001 volume 1, Sydney 16-20 July 2001. Davis, Mari, et.al (editor). Australia: International Society for Scientometrics and Informetrics.

Johnson, B. 2000. Environmental Impact: A Preliminary Citation Analysis of Local Faculty in A New Academic Program in Environmental and Human Health Applied to Collection Development in An Academic Library". Library Philosophy and Practice, 2(2). (http://unllib.unl.edu/LPP/ johnson.html, accessed April 5, 2016, hour 13.05).

Liu, M. 1993. A Study of Citing Motivation of Chinese Scientists. Journal Information Science. 19 : 13 -23. 
BACA: Jurnal Dokumentasi dan Informasi, 37 (1) Juni 2016, Halaman : 41-54

Malin M.V.1968. The Science Citation Index: A New Concept in Indexing. Library trends, Vol. 16, p. 376.

Martyn L A. 1976. Use Studies in Library Planning. Library Trends, 24(30).

Meho, Lokman I. 2007. The Rise and Rise of Citation Analysis. Physics World, 20(1), 32-36.

Narin, Francis and et. al. 1976. Evaluative Bibliometrics: The Use of Publication and Citation Analysis in the Evaluation of Scientific Activity, Cherry Hill: New Jercy, Computer Horizon Inc. p.334337.

Natakusumah, E.K. 2014. Bibliometrics Analysis of The Inkom Journal”. Jurnal BACA, Vol.36, No.1, p.112.

Nicholas, David and Maureen Ritchie. 1978. Literature and Bibliometrics. London: Clive Bingley, p.1228.

Nikko, C., \& Adetoro, N. 2007. Pioneer Bachelor Degree: Citation analysis of Covenant University Students' Research Projects. Library Philosophy and Practice. Paper 150. (http:// digitalcommons.unl.edu, acessed February 5, 2016, hour 13.01).

Olatokun, Wole Michael., \& Makinde, Olayinka. 2009. Citation Analysis of Dissertations Submitted to the Department of Animal Science, University of Ibadan Nigeria. Annals of Libraryand Information Studies, 56(2), 117-128.

Pritchard A. 1969. Statistical Bibliography An Interim Bibliography, New Western. Polytechnic school of Librarianship, London.

Reitz, Joan M. 2004. Dictionary for Library and Information Science. London: Library Unlimited.

Rousseau, R. "Publication and Citation Analysis as A Tool for Information Retrieval," In Social Information Retrieval Systems. Emerging Technologies and Applications for Searching the Web Effectively, D.Goh and S. Foo, Eds. Hershey (PA): Information Science Reference (IGI Global), 2008, pp. 252-267.

Smith, L. 1981. Citation Analysis. Library Trends 30 (1), p. 83 - 106.

Sulistyo-Basuki. 2002. Bibliometrika, Sainsmetrika dan Informetrika. Makalah Kursus Bibliometrika. Pusat Studi Jepang UI Depok, 20 - 23 Mei 2002.

Sylvia, Margaret J. 1998. Citation Analysis as An Unobtrusive Method for Journal Collection Evaluation Using Psychology Student Research Bibliographies. Collection Building, 17(1), 20-28.

Van Raan, A.F.J. 2003. The Use of Bibliometrics Analysis in Research Performance Assessment and Monitoring of Interdisciplinary Scientific Developments.

Von Ungern-Sternberg. 1995. Applications in Teaching Bibliometrics. Procceding of The 61st IFLA General Conference - Conference, August 20-25.

Ziman John M. 1968. Public knowledge: An Essay Concerning the Social Dimension of Science, Cambridge, Cambridge university press, p.58. 